\title{
A novel trans-amination process in 3-arylamino- 5,5-dimethylcyclohex-2-en-1-one with nucleophiles and antimicrobial activity of selected products
}

\author{
El Sayed H. El Ashry ${ }^{1,}$, Laila F. Awad ${ }^{1}$, Mohamed N. Abd Al Moaty ${ }^{1}$ and \\ Omayma Kh. Bdeewy ${ }^{2}$ \\ ${ }^{1}$ Chemistry Department, Faculty of Science, Alexandria University, Alexandria, Egypt \\ ${ }^{2}$ Chemistry Department Faculty of Science, Damanhour University, Egypt
}

\begin{abstract}
Reaction of dimedone with arylamines afforded the respective enaminones. Some $\mathrm{N}$-acetyl derivatives were prepared. The reaction of enaminones with hydroxylamine was found to be dependent on the nature of the arylamine moiety and the molar ratio of hydroxylamine to give the mono-, di- or tri-oximes. Cyclization of the trioxime by acetic anhydride gave dihydrobenzo[ $c][1,2,5]$ oxadiazol- $4(5 \mathrm{H})$-one-5-O-acetyloxime. Coupling of the synthesized enaminones with benzene diazonium chloride gave 2,4-bis-phenylhydrazones or a mixture of 2-mono hydrazones and bis-hydrazones depending on the nature of the arylamine moiety. Trans-amination of the arylamine of the bis hydrazones with hydroxylamine gave the same1,3-bis oxime derivative. The structures of the synthesized compounds were confirmed by IR, ${ }^{1} \mathrm{HNMR},{ }^{13} \mathrm{C}$ NMR spectra. The antimicrobial activity of some selected products showed promising results.
\end{abstract}

Keywords: Dimedone, enaminones, hydrazones, oxime, tautomerism, trans-amination.

\section{Introduction}

Enaminones are versatile reagents in organic synthesis due to their incorporation of electrophilic and nucleophilic centers as well as their tendency to form a dipolar structure capable of undergoing cyclocondensation reactions ${ }^{1-10}$. Moreover, they play a role in anionic and cationic interactions as well as charge-transfer complexes. Enaminones have been used as effective carriers for pharmacologically active groups and as synthetic intermediates in pharmaceutical developments ${ }^{11,12}$. Continuing our work on the utilization of dimedone as a precursor for heterocyclic compounds ${ }^{13-18}$, we report here the reactivity of functionalized enaminones, namely 3arylamino-5,5-dimethylcyclohex-2-en-1-ones, derived from dimedone, towards some nucleophiles and electrophiles. The anti-microbial activity of some of the synthesized compounds has been tested.

\section{Results and Discussion}

The $\beta$-enaminone derivatives are mostly obtained by reaction of a $\beta$-diketone with an amine in benzene with azeotropic removal of water ${ }^{19}$. Approaches to the acceleration of the reaction and improvement of the yield were attempted using a variety of catalysts ${ }^{20-29}$. However, grinding induced catalystfree and solvent synthesis of $\beta$-enaminones and $\beta$-enamino esters were achieved ${ }^{30}$.

Herein, we report a mild and efficient method for the synthesis of 3-arylamino-5,5-dimethylcyclohex2-en-1-one 8-13 (Scheme 1) in 88-96\% yield, by boiling dimedone with the arylamines 1-6 in acetic acid for two hours. Under similar conditions, the antipyrinyl derivative 5,5-dimethyl-3-[ $N$-(2,3dimethyl-1-phenylpyrazolin-5-on-4-yl)]aminocyclohex-2-en-1-one 14 was obtained in low yield. A better yield $(50 \%)$ of $\mathbf{1 4}$ was obtained when dimedone reacted with 7 in formic acid either under reflux for 30 minutes or at room temperature for 24 hours. The structure of $\mathbf{1 4}$ was deduced from its spectral data. Thus, the FAB mass spectrum showed a molecular ion peak at $\mathrm{m} / \mathrm{z} 326\left[\mathrm{M}^{+*}+1\right]$, and its elemental analysis agreed with the molecular formula $\mathrm{C}_{19} \mathrm{H}_{23} \mathrm{~N}_{3} \mathrm{O}_{2}$. The ${ }^{1} \mathrm{H}-\mathrm{NMR}$ spectrum of $\mathbf{1 4}$ showed the vinylic $\mathrm{C}-2$ proton as a singlet at $\delta .04 \mathrm{ppm}$ and the $\mathrm{NH}$-proton as a broad singlet at $\delta 7.98 \mathrm{ppm}$. The other signals agreed with the assigned structure (experimental section). 


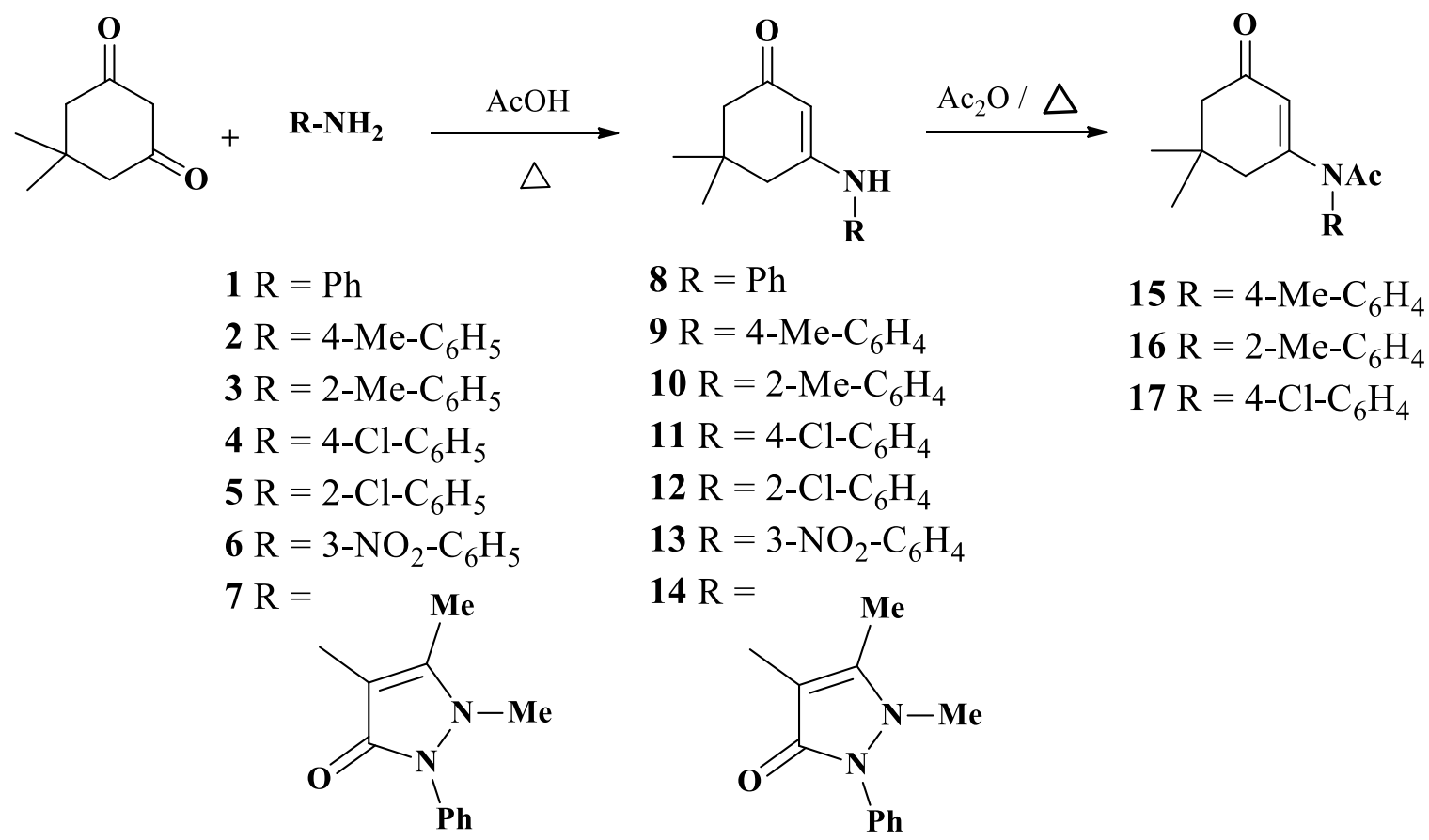

Scheme 1. Synthesis of enamine 8-14 and their N-acetyl derivatives

Acetylation of 9-11 with acetic anhydride under reflux afforded the $N$-acetyl derivatives 15-17, respectively as that deduced from their spectral analyses. The mass spectrum of $\mathbf{1 6}$ showed a molecular ion peak at $\mathrm{m} / \mathrm{z} 271$ which in agreement with the introduction of only one acetyl group. The ${ }^{1} \mathrm{H}-\mathrm{NMR}$ spectra of $\mathbf{1 5 - 1 7}$ showed the absence of the signal corresponding to the $\mathrm{NH}$-proton and the appearance of a singlet at $\delta 1.82-2.11 \mathrm{ppm}$ corresponding to only one acetyl group. Their vinylic C-2 proton resonated at $\delta 5.12-5.51 \mathrm{ppm}$, and one of the two methylene protons were assigned to the two singlets at $\delta 2.12-2.30$ and $2.46-2.73 \mathrm{ppm}$. Whereas, the second methylene of $\mathbf{1 6}$ appeared as $\mathrm{ABq}$ at $\delta 2.95$ ppm with $J_{A B q} 17.2 \mathrm{~Hz}$. The ${ }^{13} \mathrm{CNMR}$ spectra of $\mathbf{1 6}$ agreed with the assigned structure.

The reaction of $\mathbf{9}$ and $\mathbf{1 1}$ with 1.2 equivalent of hydroxylamine hydrochloride in the presence of sodium acetate for two hours afforded the mono oxime derivatives 18 and 19, respectively. Their ${ }^{1} \mathrm{H}-\mathrm{NMR}$ spectra showed a signal for the $\mathrm{N}-\mathrm{OH}$ proton at the downfield region ( $\delta 10.58 \mathrm{ppm})$ in addition to the NH-proton assigned at $\delta 11.07-11.20 \mathrm{ppm}$. When compounds 10,12 and 13 were similarly treated, only slight conversion to their mono oximes was detected by using TLC. On the other hand, increasing the molar equivalents of hydroxylamine hydrochloride to 2.4 was required to yield the dioxime 20 within 3-4 hours ${ }^{31}$. Thus, the mass spectrum of $\mathbf{2 0}$ showed a molecular ion peak at $\mathrm{m} / \mathrm{z} 170$ which indicated a trans-amination process of the aryl amine moiety had taken place with an oxime group. Also, the ${ }^{1} \mathrm{H}-\mathrm{NMR}$ spectrum of $\mathbf{2 0}$ showed the disappearance of the aryl protons and the presence of $\mathrm{D}_{2} \mathrm{O}$ exchangeable singlet of two protons intensity at $\delta 10.42$ ppm due to the two $\mathrm{N}-\mathrm{OH}$ protons.
The possible existence of the enol form $\mathbf{2 1}$ was excluded since C-4, and C-6 methylene protons were assigned for a singlet at $\delta 2.13 \mathrm{ppm}$ of four protons intensity whereas those of $\mathrm{C}-2$ were assigned at a higher frequency $(\delta 3.40 \mathrm{ppm})$ in addition to the absence of the vinyl $\mathrm{H}-2$ proton. The ${ }^{13} \mathrm{C}-\mathrm{NMR}$ of $\mathbf{2 0}$ showed signals corresponding to $\mathrm{C}-1$ and $\mathrm{C}-3$ at higher frequency region at $\delta 153.04 \mathrm{ppm}$. The two methylene carbons C-4 and C-6 were assigned at $\delta_{\mathrm{c}} 32.18 \mathrm{ppm}$ where the flanked C-2 was assigned to the higher frequency signal at $\delta_{\mathrm{c}} 44.35 \mathrm{ppm}$ because of the two oxime groups at C-1 and C-3.

When the hydroxylamine hydrochloride was increased to five equivalents in its reaction with enaminones 9-13, an unexpected product was obtained within two hours from each, in $50-76 \%$ yield which could be assigned the trioxime structure $\mathbf{2 2}^{32}$. The ${ }^{1} \mathrm{H}-\mathrm{NMR}$ spectrum of $\mathbf{2 2}$ showed the presence of two singlet signals at $\delta 2.42$ and $2.45 \mathrm{ppm}$ which were assigned to the two methylene protons. The spectrum showed the absence of signals corresponding to the aryl moiety and the presence of three $\mathrm{D}_{2} \mathrm{O}$ exchangeable signals at the downfield region at $\delta 11.33,11.89$ and $12.77 \mathrm{ppm}$ corresponding to the three N-OH protons. The presence of last three signals at a low magnetic field indicated their involvement in hydrogen bonding; two within the chelated structure and the third one can be hydrogen bonded with DMSO- $d_{6}$ that was used as a solvent (Scheme 2). The mass spectrum of $\mathbf{2 2}$ confirmed the assigned structure which showed a molecular ion peak at $\mathrm{m} / \mathrm{z} 198$ $\left[\mathrm{M}^{+*}+1\right]$. Loss of $\mathrm{NOH}$ fragment gave a bis-oxime $\mathbf{2 0}$ as the base peak at $\mathrm{m} / \mathrm{z} 170$. The ${ }^{13} \mathrm{C}$-NMR spectrum of 22 showed a signal for C-1, C-2 and C-3 at $\delta_{\mathrm{c}} 153.79 \mathrm{ppm}$ whereas $\mathrm{C}-4, \mathrm{C}-5$ and $\mathrm{C}-6$ were 
assigned at lower frequency region at $\delta \mathrm{c} 37.45,32.18$ and $44.32 \mathrm{ppm}$.

1,2,5-Oxadiazole and benzo-1,2,5-oxadiazole, as well as their $\mathrm{N}$-oxide derivatives, have potent biological activities. ${ }^{33-36}$ The synthesis of $1,2,5$ oxadiazole can be readily achieved by the dehydration of vicinal dioximes in basic or acidic media ${ }^{37-40}$. Thus, dehydrative cyclization of $\mathbf{2 2}$ with acetic anhydride under reflux for two hours gave the respective 1,2,5-oxadiazole 24 . The ${ }^{1} \mathrm{H}-\mathrm{NMR}$ spectrum of $\mathbf{2 4}$ showed the absence of $\mathrm{N}-\mathrm{OH}$ protons at the downfield region of its precursor $\mathbf{2 2}$ and the appearance of a new signal at $\delta 2.27$ attributed to an $\mathrm{N}$-O -acetyl proton that confirmed the cyclization of the vicinal dioxime to form the 1,2,5-oxadiazole $\mathbf{2 3}$ which subsequently acetylated under the reaction conditions to give 24 (Scheme 2). The cyclization process and $O$-acetylation of the oxime group were confirmed from its ${ }^{13} \mathrm{C}$-NMR $\left(\mathrm{CDCl}_{3}\right)$ spectrum that showed three signals at $\delta \mathrm{c} 134.2,144.51$ and 161.3 ppm corresponding to $\mathrm{C}-7 \mathrm{a}, \mathrm{C}-4 \mathrm{a}$, and $\mathrm{C}-4$, respectively. The $O$-acetyl group carbons were confirmed by the presence of signals at $\delta 19.85(\mathrm{Me})$ and $171.93 \mathrm{ppm}(\mathrm{CO})$.<smiles>[R]NC1=CC(=O)CC(C)(C(C)(C)C)C1</smiles>

Scheme 2. Reaction of hydroxylamine with enaminones 9-13

Attempted azo coupling of benzene diazonium chloride with the oxime derivatives $\mathbf{1 8}$ and $\mathbf{1 9}$ did not afford the respective azo derivative $\mathbf{2 5}$, and the oximes were recovered unchanged. However, coupling the enaminones9-11 with benzene diazonium chloride (1.2 molar equivalent) for four hours to give crystalline products, but they could not be assigned the expected structure 3-( $N$-aryl $)$ imino-5,5dimethylcyclohex-2-en-1-one-2-phenylhydrazone $\mathbf{2 6}$ or their azo tautomers27 (Scheme 3). 
<smiles>[R]NC1=CC(=NO)CC(C)(C)C1</smiles><smiles>CC1=CC(=O)CC(C)(C)C1</smiles>

$8 \mathrm{R}=\mathrm{Ph}$

$9 \mathrm{R}=4-\mathrm{MeC}_{6} \mathrm{H}_{4}$

$10 \mathrm{R}=2-\mathrm{MeC}_{6} \mathrm{H}_{4}$

$11 \mathrm{R}=4-\mathrm{ClC}_{6} \mathrm{H}_{4}$

$12 \mathrm{R}=2-\mathrm{ClC}_{6} \mathrm{H}_{4}$

$13 \mathrm{R}=3-\mathrm{NO}_{2} \mathrm{C}_{6} \mathrm{H}_{4}$

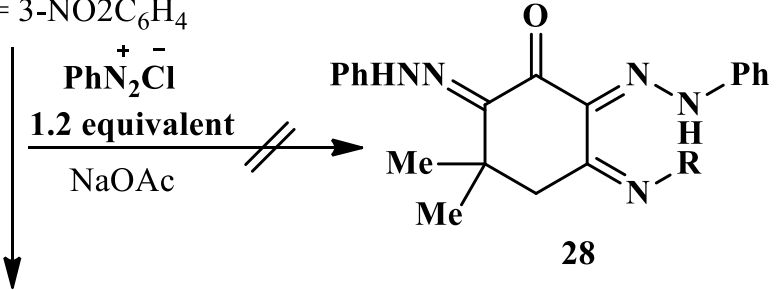

26a $\mathrm{R}=2-\mathrm{ClC}_{6} \mathrm{H}_{4}$

26b $\mathrm{R}=3-\mathrm{NO}_{2} \mathrm{C}_{6} \mathrm{H}_{4}$

$\mathrm{PhN}_{2} \mathrm{Cl}$

NaOAc<smiles>[R]N=C1CC(C)(C)CC(=O)C1=NNc1ccccc1</smiles>

26<smiles>[R]NC1=C(N=Nc2ccccc2)C(=O)CC(C)(C)C1</smiles>

27

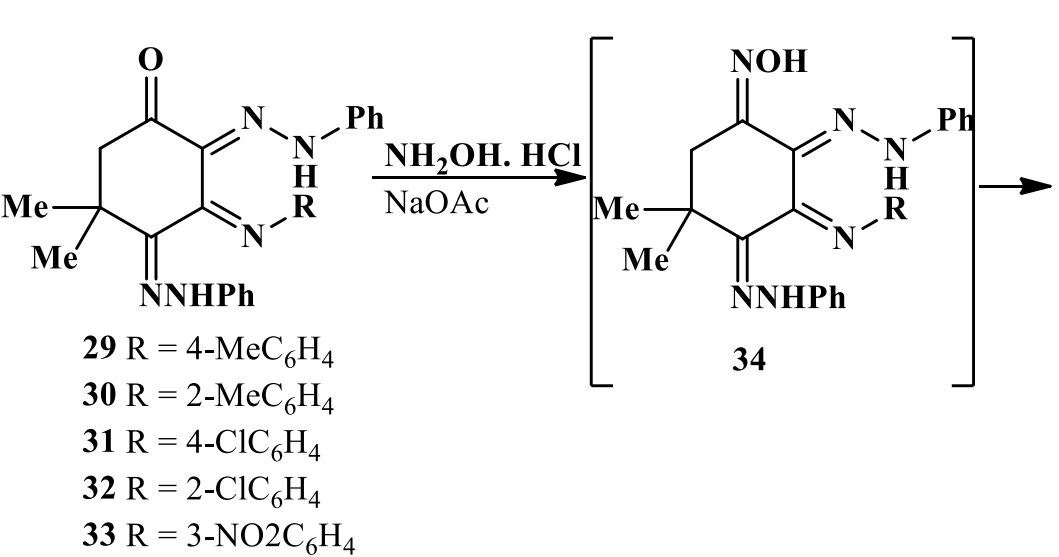

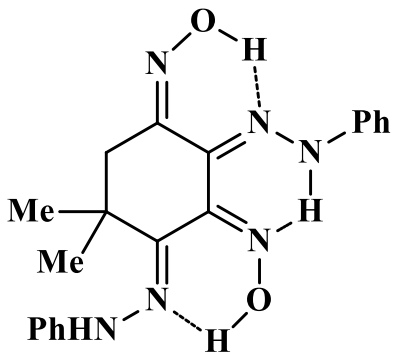

Scheme 3. Reaction of phenyl diazonium chloride with enaminones 8-13.

On the other hand, coupling the enaminones 9-11 with benzene diazonium chloride ( 5 molar equivalent) give compounds 29-31, their structures were deduced from their ${ }^{1} \mathrm{H}$ NMR spectral data which showed the absence of signals corresponding to both vinylic $\mathrm{H}-2$ and the presence of only one of the methylene singlets of dimedone moiety. The disappearance of one of the methylene groups indicated its involvement in the reaction. Moreover, extra ten protons at $\delta$ 6.61-7.38 ppm were assigned to the aromatic protons, attributed to two phenyl groups in addition to those of the pre-existing aryl group. Furthermore, the mass spectrum of $\mathbf{3 0}$ showed a molecular ion peak at $\mathrm{m} / \mathrm{z}$ $437.0\left[\mathrm{M}^{++}-1\right]$ which in agreement with the bis- hydrazone $\mathbf{3 0}$ rather than their monohydrazone $\mathbf{2 6}$. Accordingly, a double azo coupling reaction took place by successive electrophilic attacks of two diazonium ions on C-2 to give $\mathbf{2 6}$ which subsequently attacked one of the methylene group at C-6 to give $\mathbf{2 8}$ or on the methylene group at C-4to give 29-31. The formation of 29-31 rather than $\mathbf{2 8}$ was confirmed from ${ }^{13} \mathrm{C}-\mathrm{NMR}$ spectrum of $\mathbf{3 0}$ which showed three signals at the lower frequency region at $\delta_{\mathrm{c}} 28.41,37.61$ and $52.67 \mathrm{ppm}$ characteristic for two methyl groups and methylene group at C-5 and C-6, respectively whereas signals corresponding to $\mathrm{C}-4, \mathrm{C}-2$ and $\mathrm{C}-3$ were shifted to the downfield to resonate at $\delta 144.54$, 150.31 and $154.47 \mathrm{ppm}$, respectively. The 
introduction of the second phenylhydrazone group at C- 4 rather than C- 6 could be as a result of activation of this methylene group by the neighboring enamine group. The formation of the hydrazones 29-31 rather than azo tautomer was established from the assignment of only two exchangeable $\mathrm{N}-\mathrm{H}$ protons $\delta$ 14.00-14.59 ppm whereas the second N-H was overlapped with the aromatic protons for compounds 29 and 31 whereas compound $\mathbf{3 0}$ showed two $\mathrm{NH}$ signals at $\delta$ at $14.60 \mathrm{ppm}$ and $14.88 \mathrm{ppm}$. The presence of $\mathrm{N}-\mathrm{H}$ proton at the higher frequency region (14.0014.60 and 14.54-14.88) suggested its involvement in a strong intramolecular hydrogen bonding ${ }^{41}$. Moreover, the assignment of the location of the second molecule from diazonium salt at C-4 as hydrazone rather than at C- 6 as in $\mathbf{2 8}$ has been based on spectral studies of related compounds reported by Simunek et al. ${ }^{42-43}$.

On the other hand, the enaminones 12 and $\mathbf{1 3}$ under the same reaction conditions afforded a mixture of the monohydrazone (26a, 26b) and the bishydrazones (32 and 33), respectively which were fractionally separated by crystallization from ethanol. Consequently, decreasing the equivalent of benzene diazonium chloride to 0.6 molar equivalent on coupling reaction with $\mathbf{1 2}$ and $\mathbf{1 3}$ for two hours resulted in the formation of the monohydrazones $\mathbf{2 6 a}$ and 26b with a minor amount of $\mathbf{3 2}$ and 33, respectively. The ${ }^{1} \mathrm{H}-\mathrm{NMR}$ and ${ }^{13} \mathrm{C}-\mathrm{NMR}$ spectra of 32 and 33 showed a similar pattern to those of compounds 29-31. On the other hand, the ${ }^{1} \mathrm{H}-\mathrm{NMR}$ spectra of 26a and 26b showed only one exchangeable $\mathrm{N}-\mathrm{H}$ proton at $\delta$ 14.55-14.59 ppm. Moreover, two methylene protons of C-4 and C- 6 were assigned to the two singlets at $\delta$ 1.56-1.58 ppm and 2.73-2.75 ppm, respectively which confirmed the formation of the monohydrazone derivatives. Furthermore, only nine protons were assigned in the aromatic region which agrees with the assigned structure. The ${ }^{13} \mathrm{C}-\mathrm{NMR}$ spectra of $\mathbf{2 6 \mathbf { a }}$ and $\mathbf{2 6 \mathbf { b }}$ also confirmed the introduction of the monohydrazone moiety since three signals corresponding to C-5, C-4 and C-6 were assigned at $\delta_{\mathrm{c}} 37.72-37.91,37.92-37.99$ and 52.52$52.64 \mathrm{ppm}$, respectively whereas the other three carbons C-2, C-3 and C-1 were resonated at higher frequency region at $\delta_{c} 145.41-152.54,155.49-155.51$ and 196.59- $197.15 \mathrm{ppm}$, respectively.

Treatment of compounds $\mathbf{2 9 - 3 3}$ with excess hydroxylamine hydrochloride in the presence of sodium acetate in ethanol under reflux did not afford the respective oxime derivative $\mathbf{3 4}$, but the same crystalline product $\mathbf{3 5}$ resulted from each of them. Its elemental analysis as well as its mass spectrum which showed a molecular ion peak at $\mathrm{m} / \mathrm{z} 378$, were inconsistent with $\mathbf{3 4}$, but in agreement with the molecular formula $\mathrm{C}_{20} \mathrm{H}_{22} \mathrm{~N}_{6} \mathrm{O}_{2}$ indicating the displacement of the arylamine residue by an oxime group. The ${ }^{1} \mathrm{HNMR}$ spectrum of the isolated product, measured in deuterated chloroform, showed the absence of signals corresponding to the aryl moiety, and the presence of signals corresponding to ten protons of two phenyl groups. Moreover, four exchangeable singlets at $\delta 8.22,12.35,12.93$ and $15.06 \mathrm{ppm}$ can be assigned to the $2 \mathrm{OH}$, and $2 \mathrm{NH}$ and at least two of them are involved in hydrogen bonding.

\section{Antimicrobial study for some selected compounds}

Compounds 11, 14, 17, 18, 19, 29, 31 and 35 were screened for their antimicrobial activity against $S$. aureus and $C$. albicans using agar diffusion method ${ }^{44}$ and ampicillin and clotrimazole as references. The results (Table 1) showed that compounds 14, 17, 18, and 19 have moderate inhibition against $S$. aureus (IZ 21-28 mm). On the other hand, the presence of the phenylhydrazone moieties in compounds 29 and 31 resulted in the loss of activity against $\mathrm{S}$. aureus. However, the chloro compound $\mathbf{1 9}$ showed a higher antimicrobial activity (IZ $30-31 \mathrm{~mm}$ ) against $C$. albicans and $p$-tolyl analogue $\mathbf{1 8}$ showed the same activity (IZ $23 \mathrm{~mm}$ ) compared to that of clotrimazole. The other tested compounds showed lower inhibition activity (IZ 14-20).

Table 1. Antimicrobial activity of some selected compounds.

\begin{tabular}{|l|l|l|l|}
\hline \multirow{2}{*}{ Compd. No. } & Inhibition zone (IZ) & \\
\cline { 2 - 3 } & S. aureus & C. albicans \\
\hline $\mathbf{1 1}$ & 24 & 20 & \\
$\mathbf{1 4}$ & 21 & 18 & \\
\hline $\mathbf{1 7}$ & 24 & 20 \\
\hline $\mathbf{1 8}$ & 24 & 23 \\
\hline $\mathbf{1 9}$ & 28 & $30-31$ \\
\hline $\mathbf{2 9}$ & - & 15 \\
\hline $\mathbf{3 1}$ & - & $14-15$ \\
\hline $\mathbf{3 5}$ & 13 & 19 \\
\hline Ampicillin & 35 & - \\
\hline Chlotrimazole & - & 23 & \\
\hline
\end{tabular}




\section{Conclusion}

The enaminones derived from dimedone have proved its utility as reactive intermediates upon reaction with nucleophilic and electrophilic reagents. The formation of the oxime derivatives can be rationalized by nucleophilic attack of hydroxylamine at $\mathrm{C}-1$ carbonyl group to give the respective $\mathrm{C}-1$ mono oximes that underwent a trans-amination process of the arylamine moiety with hydroxylamine to form the bis-oximes. Further reaction of the bis oxime with $\mathrm{NH}_{2} \mathrm{OH}$, probably at the more reactive methylene carbon $\mathrm{C}-2$ rather than $\mathrm{C}-6$ gave the tri-oxime. The preference for the first attack of hydroxylamine at C-1 rather than C-3 can be deduced from the formation of the mon-oximes without affecting the arylamine residue. The trans-amination process has supported by a displacement of such type, but with hydrazine, of 3-benzylamino group in 3-benzylamino-2-carboxamido derivative of dimedone with hydrazine ${ }^{45}$, and reactions of enamines with nitrogen nucleophiles ${ }^{3}$. Moreover, good antimicrobial activity against $S$. aureus and C. albican was shown.

\section{Experimental}

Melting points were determined with a Mel-Temp apparatus and are uncorrected. TLC was performed on Baker-Flex silica gel 1B-F $(1.5-5.0 \mathrm{~cm})$ plates, and the spots were detected by UV light absorption. IR spectra were recorded in a matrix of $\mathrm{KBr}$ with PerkinElmer 1430 spectrometer. ${ }^{1} \mathrm{H}$ NMR spectra were recorded on Jeol spectrometer $(500 \mathrm{MHz})$ and Bruker $\mathrm{AC}(300 \mathrm{MHz})$ spectrometer. Chemical shifts $(\delta)$ are given in ppm relative to the signal for TMS as an internal standard. ${ }^{13} \mathrm{CNMR}$ were recorded on the Bruker Avance AV spectrometer at $75 \mathrm{MHzChemical}$ shifts $(\delta)$ are given in ppm. Mass spectra were recorded using electron ionization (EI) on a Finnigan MAT 312 spectrometer orJeol (JMS.600H) instrument and fast-atom-bombardment (FAB) on a Kratos MS50 spectrometer.

\section{3-N-(Aryl)amino-5,5-dimethylcyclohex-2-en-1- ones (8-14).}

Method a. A mixture of dimedone $(0.01 \mathrm{~mol})$ and arylamines1-6 or 4-aminoantipyrine $7(0.01 \mathrm{~mol})$ in acetic acid $(5 \mathrm{~mL})$ was heated under reflux for 2 hours. The reaction mixture was left to cool, then poured onto cold water $(50 \mathrm{~mL})$. The product was filtered off and crystallized from ethanol.

Method b. A mixture of dimedone $(0.01 \mathrm{~mol})$ and 4 aminoantipyrine $(0.01 \mathrm{~mol})$ was heated under reflux in formic acid $(98 \%, 20 \mathrm{~mL})$ for $30 \mathrm{~min}$, or left at room temperature for 24 hours then evaporated under reduced pressure. The residue was washed with warm water and then re-crystallized from ethanol to give $\mathbf{1 4}$ (50\% yield) identical with that obtained from method a.
5,5-Dimethyl-3-N-(Phenyl)amino-cyclohex-2-en-1one (8).

Yellow crystals (70 \%yield); m. p. $167-168^{\circ} \mathrm{C}$, lit. ${ }^{19}$ m.p. $165-167^{\circ} \mathrm{C}$.

5,5-Dimethyl-3-N-(4-methylphenyl)amino-cyclohex-2-en-1-one (9).

Pale yellow crystals ( $79 \%$ yield ); m. p. $202-203{ }^{\circ} \mathrm{C}$; lit. ${ }^{19}$ m. p. $203-204{ }^{\circ} \mathrm{C}$,

${ }^{1} \mathrm{H} \mathrm{NMR}\left(\mathrm{CDCl}_{3}, 500 \mathrm{MHz}\right) \delta_{\mathrm{H}} \mathrm{ppm}: 1.10(\mathrm{~s}, 6 \mathrm{H}$, 2Me), 2.18 (s, 2H, $\mathrm{CH}_{2}$ ), 2.30 (s, 3H, Me), 2.31 (s, 2H, $\left.\mathrm{CH}_{2}\right), \quad 5.49$ (s, $\left.1 \mathrm{H}, \quad \mathrm{H}-2\right), \quad 6.63 \quad\left(\mathrm{bs}, \quad 1 \mathrm{H}, \quad \mathrm{D}_{2} \mathrm{O}\right.$ exchangeable, $\mathrm{NH}), 7.02$ (d, 2H, J 8.4 Hz, Ar-H), 7.11 (d, 2H,J $8.4 \mathrm{~Hz}, \mathrm{Ar}-\mathrm{H})$.

\section{5,5-Dimethyl-3-N-(2-methylphenyl)amino-cyclo-} hex-2-en-1-one $(10)$.

Pale yellow crystals (88\% yield); m. p. $138-140{ }^{\circ} \mathrm{C}$, lit. ${ }^{19}$ m.p. $136^{\circ} \mathrm{C}$.

${ }^{1} \mathrm{H} \mathrm{NMR}\left(\mathrm{CDCl}_{3}, 500 \mathrm{MHz}\right) \delta_{\mathrm{H}} \mathrm{ppm}: 1.05(\mathrm{~s}, 6 \mathrm{H}$, 2Me), 2.19 (s, 2H, $\left.\mathrm{CH}_{2}\right), 2.22$ (s, 3H, Me), 2.35 (s, $2 \mathrm{H}$, $\left.\mathrm{CH}_{2}\right), 4.95$ (s, 1H, H-2), 7.06-7.20 (m, 5H, ArH+NH).

3-N-(4-Chlorophenyl)amino-5,5-dimethylcyclohex-2-en-1-one (11).

Pale yellow crystals $(60 \%$ yield $) ;$ m. p. $205-206^{\circ} \mathrm{C}$, lit. ${ }^{19}$ m. p. $209-210{ }^{\circ} \mathrm{C}$.

\section{3-N-(2-Chlorophenyl)amino-5,5-dimethylcyclo-} hex-2-en-1-one (12).

Pale yellow crystals (96\% yield); m. p. $144-145^{\circ} \mathrm{C}$, lit. ${ }^{19}$ m.p. $141-142{ }^{\circ} \mathrm{C}$.

${ }^{1} \mathrm{H}$ NMR $\left(\mathrm{CDCl}_{3}, 500 \mathrm{MHz}\right) \delta_{\mathrm{H}} \mathrm{ppm}: 1.09(\mathrm{~s}, 6 \mathrm{H}$, 2Me), $2.20\left(\mathrm{~s}, 2 \mathrm{H}, \mathrm{CH}_{2}\right), 2.35\left(\mathrm{~s}, 2 \mathrm{H}, \mathrm{CH}_{2}\right), 5.43$ $(\mathrm{s}, 1 \mathrm{H}, \mathrm{H}-2), 6.68$ (s, 1H, $\mathrm{D}_{2} \mathrm{O}$ exchangeable, $\left.\mathrm{NH}\right)$, $7.16(\mathrm{t}, 1 \mathrm{H}, J 7.65 \mathrm{~Hz}, \mathrm{Ar}-\mathrm{H}), 7.22(\mathrm{t}, 1 \mathrm{H}, J 7.65 \mathrm{~Hz}$, Ar-H), 7.35, 7.40 (2d, 2H, J 7.65 Hz, Ar-H).

\section{5,5-Dimethyl-3-N-(3-nitrophenyl)amino-cyclohex-} 2-en-1-one(13).

Pale yellow crystals (96\% yield); m.p. $173-174{ }^{\circ} \mathrm{C}$, lit. ${ }^{19}$ m. p. $174-175^{\circ} \mathrm{C}$,

${ }^{1} \mathrm{H} \mathrm{NMR}\left(\mathrm{CDCl}_{3}, 500 \mathrm{MHz}\right) \delta_{\mathrm{H} p p m: 1.08}(\mathrm{~s}, 6 \mathrm{H}$, 2Me), $2.30\left(\mathrm{~s}, 2 \mathrm{H}, \mathrm{CH}_{2}\right), 2.53\left(\mathrm{~s}, 2 \mathrm{H}, \mathrm{CH}_{2}\right), 5.77$ (s, 1H, $\mathrm{D}_{2} \mathrm{O}$ exchangeable, $\left.\mathrm{N}-\mathrm{H}\right), 7.25(\mathrm{~s}, 1 \mathrm{H}, \mathrm{H}-2)$, 7.51-7.60 (m, 2H, Ar-H), 8.03 (d, 2H, J 8.6 Hz, ArH).

\section{5,5-Dimethyl-3-N-[(2,3-dimethyl-1-} phenylpyrazolin-5-one-4-yl)]aminocyclohex-2-en1-one (14).

Pale yellow crystals (22\% yield ) from ethanol; m.p. $218^{\circ} \mathrm{C}$

IR (solid, KBr, vmax, $\left.\mathrm{cm}^{-1}\right)$ : $3234(\mathrm{NH}), 1649$ and $1612(\mathrm{CO}, \mathrm{C}=\mathrm{C})$;

${ }^{1} \mathrm{H}$ NMR $\left(\mathrm{CDCl}_{3}, 300 \mathrm{MHz}\right) \delta_{\mathrm{H}} \mathrm{ppm}: 1.08(\mathrm{~s}, 6 \mathrm{H}$, 2Me), 2.08 (s, 3H, Me), $2.13\left(\mathrm{~s}, 2 \mathrm{H}, \mathrm{CH}_{2}\right), 2.28$ (s, 2H, $\mathrm{CH}_{2}$ ), 3.06 (s, 3H, N-Me), 5.04 ( s, 1H, H-2), 7.31-7.49 (m, 5H, Ar-H), 7.98 (bs, 1H, $\mathrm{D}_{2} \mathrm{O}$ exchangeable, NH). FABMS: m/z $326\left(\mathrm{M}^{++}+1,100\right.$ $\%)$.

Analysis Calcd. for $\mathrm{C}_{19} \mathrm{H}_{23} \mathrm{~N}_{3} \mathrm{O}_{2}$ (325.39):C, 70.12; H, 7.12; N, 12.60. Found: C, 70.32; H, 7.00; N, 12.74. 


\section{3-(N-Acetyl-N-Aryl)amino-5,5-dimethylcyclohex-} 2-en-1-ones (15-17).

General method. A suspension of $\mathbf{9}$ - 11 (5 mmol) in acetic anhydride $(15 \mathrm{~mL})$ was heated under reflux for 1hour. The reaction mixture was cooled then poured onto crushed ice. The separated syrup was dissolved in chloroform, and the solution was washed with a dilute solution of $\mathrm{NaHCO}_{3}$ in water. The chloroform layer was dried over anhydrous sodium sulfate, then evaporated and the residue was recrystallized from ethanol to give 15-17, respectively.

\section{3-(N-Acetyl-N-4-methylphenyl)-5,5-dimethyl- cyclohex-2-en-1-one(15).}

Pale yellow crystals (23\% yield ); m.p. $78-80{ }^{\circ} \mathrm{C}$; IR (solid, KBr, vmax, $\mathrm{cm}^{-1}$ ): 1689, 1653 (CO);

${ }^{1} \mathrm{H}-\mathrm{NMR}\left(\mathrm{CDCl}_{3}, 500 \mathrm{MHz}\right) \delta_{\mathrm{H}} \mathrm{ppm}: 1.06(\mathrm{~s}, 6 \mathrm{H}$, 2Me), 1.94 (s, 3H, Ac), $2.30\left(\mathrm{~s}, 2 \mathrm{H}, \mathrm{CH}_{2}\right), 2.35$ (s, $3 \mathrm{H}, \mathrm{Me}$ ), 2.73 (s, 2H, $\mathrm{CH}_{2}$ ), 5.34 (s, 1H, H-2), 7.00 (d, 2H, J $8.4 \mathrm{~Hz}, \mathrm{Ar}-\mathrm{H}), 7.24$ (d, 2H, J $8.4 \mathrm{~Hz}, \mathrm{Ar}-\mathrm{H}$ ). Analysis Calcd. for $\mathrm{C}_{17} \mathrm{H}_{21} \mathrm{NO}_{2}$ (271.35): C, 75.52; H, 7.80; N, 5.16. Found: C, 75.23; H, 7.33; N, 5.26.

\section{3-(N-Acetyl-N-2-methylphenyl)-5,5-dimethyl- cyclohex-2-en-1-one(16).}

Pale yellow crystals (22\% yield ); m.p. $103-105^{\circ} \mathrm{C}$; ${ }^{1} \mathrm{H}-\mathrm{NMR}\left(\mathrm{CDCl}_{3}, 500 \mathrm{MHz}\right) \delta_{\mathrm{H}} \mathrm{ppm}: 1.04,1.06$ (2s, 6H, 2Me), 1.82 (s, 3H, Ac), 2.17 (s, 3H, Me), 2.23 (s, 2H, $\left.\mathrm{CH}_{2}\right), 2.95\left(\mathrm{ABq}, 2 \mathrm{H}, J 17.2 \mathrm{~Hz}, \mathrm{CH}_{2}\right), 5.12$ (s, 1H, H-2), 7.05 (d, 1H, J 7.65 Hz,Ar-H), 7.26-7.33 (m, 3H, Ar-H),

${ }^{13} \mathrm{C}$ NMR $\left(\mathrm{CDCl}_{3}\right) \delta_{\mathrm{c}}$ ppm: $21.4\left(\mathrm{COCH}_{3}\right), 25.3$ (2-Me), 27.9, 28.4 (2Me), 34.1 (C-5), $43.4(\mathrm{C}-4), 50.5$ (C-6), 115.6, 127.9, 129.0,129.4, 132.0, 135.5 (Ar-C), 139.7 (C-2), 160.4 (C-3), 171.2 NCO and 199.7 (C-1).

MS (EI) m/z (\%): $271\left(20, \mathrm{M}^{+\cdot}\right), 228\left(85, \mathrm{M}^{+\cdot}\right.$ $\mathrm{COCH}_{3}$ ), 214 (base peak $\mathrm{M}^{+\cdot}-\mathrm{N}-\mathrm{CO}-\mathrm{CH}_{3}$ ).

Analysis Calcd. for $\mathrm{C}_{17} \mathrm{H}_{21} \mathrm{NO}_{2}(271.35): \mathrm{C}, 75.52 ; \mathrm{H}$, 7.80; N, 5.16. Found: C, 75.33; H, 7.60; N, 5.26.

3-(N-Acetyl-N-4-chlorophenyl)-5,5-dimethylcyclohex-2-en-1-one (17).

Colorless crystals ( $90 \%$ yield); m.p. $118^{\circ} \mathrm{C}$;

IR (solid, KBr, vmax, $\mathrm{cm}^{-1}$ ): 1690, 1653 (CO),

${ }^{1} \mathrm{H}-\mathrm{NMR}$ (DMSO- $\left.d_{6}, 500 \mathrm{MHz}\right) \delta_{\mathrm{H}} \mathrm{ppm}: 0.97(\mathrm{~s}, 6 \mathrm{H}$, 2Me), 2.11 (s, 3H, Ac), 2.12 (s, 2H, $\mathrm{CH}_{2}$ ), 2.46 (s, 2H, $\mathrm{CH}_{2}$ ), 5.51 (s, 1H, H-2), 7.39 (d, 2H, J 8.6 Hz, Ar-H), 7.58 (d, 2H, J8.6 Hz, Ar-H).

Analysis Calc for $\mathrm{C}_{16} \mathrm{H}_{18} \mathrm{NO}_{2} \mathrm{Cl}$ (291.765): C, 65.68; H, 6.21; N, 4.80. Found: C, 65.79; H, 6.27; N, 4.93.

\section{3-N-(Aryl)amino-5,5-dimethylcyclohex-2-en-1- oximes(18-19).}

General method. A solution of $\mathbf{9}$ or $\mathbf{1 1}(10 \mathrm{mmol})$ in ethanol $(30 \mathrm{~mL})$ was treated with hydroxylamine hydrochloride $(12 \mathrm{mmol})$ and sodium acetate (12 mmol). The mixture was boiled under reflux for 2 hours. The solution was then concentrated under reduced pressure. The product was filtered, washed with water, dried then crystallized from ethanol.

\section{5,5-Dimethyl-3-N-(4-methylphenyl)aminocyclo-} hex-2-en-1-oxime (18).

Colorless needles (82\% yield); m.p. $177-179{ }^{\circ} \mathrm{C}$;

IR (solid, $\mathrm{KBr}$, vmax, $\left.\mathrm{cm}^{-1}\right)$ : 3237(NH), $1615(\mathrm{C}=\mathrm{N})$. ${ }^{1} \mathrm{H}-\mathrm{NMR}\left(\mathrm{DMSO}-d_{6}, 300 \mathrm{MHz}\right) \delta_{\mathrm{H}} \mathrm{ppm}: 1.03$ (s, 6H, 2Me), 2.32 (s, 3H, Me), 2.38 (s, 2H, $\left.\mathrm{CH}_{2}\right), 2.55$ (s, 2H, $\mathrm{CH}_{2}$ ), 5.68 (s, 1H, H-2), 7.18 (d, 2H, J $\left.8.0 \mathrm{~Hz}, \mathrm{Ar}-\mathrm{H}\right)$, 7.29 (d, 2H, J 8.0 Hz, Ar-H), 10.58, 11.07, (2s, 2H, $\mathrm{D}_{2} \mathrm{O}$ exchangeable $\left.\mathrm{OH}, \mathrm{NH}\right)$.

FABMS: $\mathrm{m} / \mathrm{z} 245\left(\mathrm{M}^{+\cdot}+1,100 \%\right)$.

Analysis Calc for $\mathrm{C}_{15} \mathrm{H}_{20} \mathrm{~N}_{2} \mathrm{O}$ (244.33): C, 73.73; H, 8.25; N, 11.46. Found: C, 73.59; H, 8.34; N, 11.37.

\section{3-N-(4-Chlorophenyl)amino-5,5-dimethylcyclo-} hex-2-en-1-oxime(19).

Colorless crystals (76\% yield ); m.p. $210-211^{\circ} \mathrm{C}$; IR (solid, $\mathrm{KBr}$, vmax, $\left.\mathrm{cm}^{-1}\right): 3228(\mathrm{NH}), 1616(\mathrm{C}=\mathrm{N})$; ${ }^{1} \mathrm{H}-\mathrm{NMR}$ (DMSO- $\left.d_{6}, 500 \mathrm{MHz}\right) \delta_{\mathrm{H}} \mathrm{ppm}: 1.05$ (s, 6H, 2Me), 2.39 (s, 2H, $\left.\mathrm{CH}_{2}\right), 2.55\left(\mathrm{~s}, 2 \mathrm{H}, \mathrm{CH}_{2}\right), 5.75$ (s, 1H, H-2), 7.33 (d, 2H, J 8.3 Hz, Ar-H), 7.55 (d, 2H,

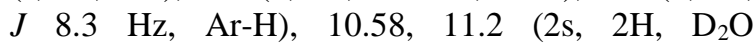
exchangeable $\mathrm{OH}, \mathrm{NH}$ ).

Anal. Calc for $\mathrm{C}_{14} \mathrm{H}_{17} \mathrm{~N}_{2} \mathrm{OCl}$ (264.757): C, 63.50; H, 6.47; N, 10.58. Found: C, 63.35; H, 6.64; N, 10.39 .

\section{5,5-Dimethylcyclohexane-1,3-dioxime (20).}

General method. A solution of 10,12 and13 (5 mmol) in ethanol $(30 \mathrm{~mL})$ was treated with hydroxylamine hydrochloride $(12.20 \mathrm{mmol})$ and sodium acetate $(12.20 \mathrm{mmol})$. The mixture was boiled under reflux for 3-4hours. The solution was then concentrated under reduced pressure. The residue was filtered, washed with water and dried. It was crystallized from ethanol to give $\mathbf{2 0}$ as colorless crystals in (70.4\% yield) from 10, (70\% yield) from 12 and (45\% yield) from 13;

m.p. $220-222{ }^{\circ} \mathrm{C}$ lit. $^{31}$ m. p. $221-223^{\circ} \mathrm{C}$;

${ }^{1} \mathrm{H}-\mathrm{NMR}\left(\mathrm{DMSO}-d_{6}, 500 \mathrm{MHz}\right) \delta_{\mathrm{H}} \mathrm{ppm}: 0.86(\mathrm{~s}, 6 \mathrm{H}$, $2 \mathrm{Me}$ ), 2.13 (s, 4H, 2CH $), 3.40\left(\mathrm{~s}, 2 \mathrm{H}, \mathrm{CH}_{2}\right), 10.42$ (s, 2H, $\mathrm{D}_{2} \mathrm{O}$ exchangeable $2 \mathrm{NOH}$ ).

${ }^{13} \mathrm{C}$ NMR ((DMSO- $\left.d_{6}\right) \delta_{\mathrm{c}}$ ppm: 23.6 (2Me), 27.8 (C-5), 32.1 (C-4, C-6), 44.3 (C-2), 153.0 (C-1, C-3); MS (EI) m/z (\%): $170 \mathrm{M}^{+}$.

Analysis Calcd. for $\mathrm{C}_{8} \mathrm{H}_{14} \mathrm{~N}_{2} \mathrm{O}_{2}$ (170.21): C,56.45; H,8.29; N, 16.46; O, 18.80. Found: C, 56.30; H,8.10; N, 16.20;

\section{5,5-Dimethylcyclohexan-1,2,3-trioxime (22).}

General method. A solution of 9-13 $(5 \mathrm{mmol})$ in ethanol $(30 \mathrm{~mL})$ was treated with hydroxylamine hydrochloride $(25 \mathrm{mmol})$ and sodium acetate $(25 \mathrm{mmol})$. The mixture was boiled under reflux for 2hoursthe mixture was then concentrated under reduced pressure. The residue was filtered, washed with water and dried, then crystallized from ethanol to give $\mathbf{2 2}$ as colorless crystals in $70 \%$ yield from $\mathbf{9}, 76$ $\%$ yield from $10,68 \%$ yield from $11,60 \%$ yield from 12 and $50 \%$ yield from $\mathbf{1 3}$;

m.p.,200 ${ }^{\circ} \mathrm{C}$ lit. ${ }^{32}$ m.p. $200-201{ }^{\circ} \mathrm{C}$, 
${ }^{1} \mathrm{H}-\mathrm{NMR}$ DMSO- $\left.d_{6}, 500 \mathrm{MHz}\right) \delta_{\mathrm{H}} \mathrm{ppm}: 0.91$ (s, 6H, 2Me), 2.42 (s, 2H, $\mathrm{CH}_{2}$ ), 2.45 (s, $2 \mathrm{H}, \mathrm{CH}_{2}$ ), 11.33, $11.89,12.77\left(3 \mathrm{~s}, 3 \mathrm{H}, \mathrm{D}_{2} \mathrm{O}\right.$ exchangeable, $\left.3 \mathrm{NOH}\right)$, ${ }^{13} \mathrm{C}$ NMR (DMSO- $\left.d_{6}\right) \delta_{\mathrm{c}}$ ppm: $27.8(2 \mathrm{Me}), 32.1(\mathrm{C}-5)$, 37.4 (C-4), 44.3 (C-6), 153.7 (C-1, C-2, C-3) MS (EI) m/z (\%): $198.1\left(18,\left(\mathrm{M}^{+\cdot}-1\right), 170\left(100, \mathrm{M}^{+}\right.\right.$$\left.\mathrm{NH}_{2} \mathrm{OH}\right)$.

Analysis Calc for $\mathrm{C}_{8} \mathrm{H}_{13} \mathrm{~N}_{3} \mathrm{O}_{3}$ (199.2): C, 48.23; $\mathrm{H}$, 6.58; N, 21.09. Found: C, 48.20. H, 6.30; N, 20.80.

\section{6,6-Dimethyl-6,7-dihydrobenzo $[c][1,2,5]$ oxa-} diazol-4(5H)-one- $O$-acetyloxime $(24)$.

A solution of $22(0.9 \mathrm{mmol})$ in acetic anhydride $(5 \mathrm{~mL})$ was boiled under reflux for 2 hours. The reaction mixture was then left to cool and poured onto cold water $(30 \mathrm{~mL})$. The product was filtered off purified by column chromatography using hexaneethylacetate (4:1), then crystallized from ethanol to give $\mathbf{2 4}$ as colorless crystal (37\% yield); m.p. 130-132 $\left.{ }^{\circ} \mathrm{C},{ }^{1} \mathrm{H}-\mathrm{NMR}\left(\mathrm{CDCl}_{3}\right) 500 \mathrm{MHz}\right) \delta_{\mathrm{H}} \mathrm{ppm}: 1.00(\mathrm{~s}, 6 \mathrm{H}$, $2 \mathrm{Me}$ ), 1.59 (s, $\left.2 \mathrm{H}, \mathrm{CH}_{2}\right), 2.27$ (s, 3H, $\left.\mathrm{COCH}_{3}\right), 3.63$ $\left(\mathrm{s}, 2 \mathrm{H}, \mathrm{CH}_{2}\right),{ }^{13} \mathrm{C}-\mathrm{NMR}\left(\mathrm{CDCl}_{3}\right) \delta_{\mathrm{c}} \mathrm{ppm}: 19.8$ $\left(\mathrm{COCH}_{3}\right), 28.6(2 \mathrm{Me}), 29.1$ (C-6), 42.4, 47.2 (C-7, C-5), 134.2 (C-7a), 144. (C-4a), 161. (C-4), 171.9 $\left(\mathrm{COCH}_{3}\right)$.

Analysis.Calc for $\mathrm{C}_{10} \mathrm{H}_{13} \mathrm{~N}_{3} \mathrm{O}_{3}(223.22)$ : C, 53.80; H, $5.87 ; \mathrm{N}, 18.82 ; \mathrm{O}, 21.50$. Found: C, 53.62. H, 5.53; N, 18.78; O, 21.48.

\section{3-N-(Aryl)imino-5,5-dimethyl-2-}

(phenylhydrazone)cyclohexanone (26a-b) Method a. A solution of aniline (5 mmol) in conc. hydrochloric acid $(1.5 \mathrm{~mL})$ and water $(2.5 \mathrm{~mL})$ was cooled to $0{ }^{\circ} \mathrm{C}$ and treated with a chilled solution of sodium nitrite $(6 \mathrm{mmol})$ in water $(2.5 \mathrm{~mL})$. The resulting solution of benzenediazonium chloride was added with stirring to a solution of $\mathbf{1 2 - 1 3}(8.0 \mathrm{mmol})$ and sodium acetate $(4.75 \mathrm{mmol})$ in methanol $(30 \mathrm{~mL})$. The reaction mixture was maintained at $0{ }^{\circ} \mathrm{C}$ for 2 hours. The product was filtered off, washed with methanol and then re-crystallized from ethanol.

3-N-(2-Chlorophenyl)imino-5,5-dimethyl-2(phenylhydrazone)cyclohexanone (26a). Red plates (75\% yield); m.p. $162-164{ }^{\circ} \mathrm{C}$;

IR (solid, $\mathrm{KBr}$, vmax, $\mathrm{cm}^{-1}$ ): 3441 (NH), 1642 (CO); ${ }^{1} \mathrm{H}-\mathrm{NMR}\left(\mathrm{CDCl}_{3}, 500 \mathrm{MHz}\right) \delta_{\mathrm{H}} \mathrm{ppm}: 1.45(\mathrm{~s}, 6 \mathrm{H}$, 2Me), 1.58 (s, 2H, $\mathrm{CH}_{2}$ ), 2.75 (s, $\left.2 \mathrm{H}, \mathrm{CH}_{2}\right), 6.60-7.10$ (m, 4H, Ar-H), 7.18-7.25 (m, 2H, Ar-H), 7.29-7.38 (m, 2H, Ar-H), 7.45 (dd, 1H, J $10 \mathrm{~Hz}$, Ar-H), 14.59 (s, $1 \mathrm{H}, \mathrm{D}_{2} \mathrm{O}$ exchangeable, $\mathrm{NH}$ ).

${ }^{13} \mathrm{CNMR}\left(\mathrm{CDCl}_{3}\right) \delta_{\mathrm{c}} \mathrm{ppm}: 28.5(2 \mathrm{Me}), 37.7,37.9(\mathrm{C}-5$, C-4), $52.6 \quad$ (C-6),114.1, 115.9, 120.7, 121.7, 129.1,129.2, 129.9, 136.7, 144.4 (Ar-C), 148.4 (C-2), 155.5(C-3), 196.5 (C-1).

Anal.Calc for $\mathrm{C}_{20} \mathrm{H}_{20} \mathrm{~N}_{3} \mathrm{OCl}$ (353.837): C,67.88; $\mathrm{H}$ 5.69; N,11.87.Found: C,67.99; H 5.49; N,11.88.

\section{5,5-Dimethyl-3- $N$-(3-nitrophenyl)imino-2-} (phenylhydrazone)cyclohexanone(26b). It was obtained as red plates (70\% yield); m.p.160$161^{\circ} \mathrm{C}$;
IR (solid, KBr, vmax, $\mathrm{cm}^{-1}$ ): $3445(\mathrm{NH}), 1640$ (CO); ${ }^{1} \mathrm{H}-\mathrm{NMR}\left(\mathrm{CDCl}_{3}, 500 \mathrm{MHz}\right) \delta_{\mathrm{H}} \mathrm{ppm}: 1.42(\mathrm{~s}, 6 \mathrm{H}$, 2Me), $1.56\left(\mathrm{~s}, 2 \mathrm{H}, \mathrm{CH}_{2}\right), 2.73\left(\mathrm{~s}, 2 \mathrm{H}, \mathrm{CH}_{2}\right), 6.58$ (t, 1H, J10 Hz, $5 \mathrm{~Hz}$, Ar-H), 7.00 (t, 1H, Ar-H), 7.08 (t, 1H, Ar-H), 7.19 (t, 3H, Ar-H), $7.48(\mathrm{t}, 1 \mathrm{H}, \mathrm{Ar}-\mathrm{H})$, 7.85 (s, 1H, Ar-H), 7.94 (d, 1H, Ar-H), 14.55 (s, 1H, $\mathrm{D}_{2} \mathrm{O}$ exchangeable, $\left.\mathrm{N}-\mathrm{H}\right)$.

${ }^{13} \mathrm{C}-\mathrm{NMR}\left(\mathrm{CDCl}_{3}\right) \delta_{\mathrm{c}}$ ppm:28.4 (2Me),37.9, 37.9 (C-5, C-4), 52.5 (C-6), 114.3, 115.7, 117.1, 125.34, 126.1, 129.3, 136.5, 144.0, 149.2 (Ar-C), 152.5 (C-2), 155.4 (C-3), 197.1 (C-1).

Anal.Calc for $\mathrm{C}_{20} \mathrm{H}_{20} \mathrm{~N}_{4} \mathrm{O}_{3}$ (364.39):C, 65.92; H 5.53; N, 15.37. Found: C, 65.80; H 5.57; N, 15.19.

\section{3- $N$-(Aryl)imino-5,5-dimethyl-2,4-bis-} (phenylhydrazone)cyclohexanones(29-33).

General method. A solution of aniline $(10 \mathrm{mmol})$ in conc. hydrochloric acid $(3.0 \mathrm{~mL})$ and water $(5 \mathrm{~mL})$ was cooled to $0{ }^{\circ} \mathrm{C}$ and treated with a chilled solution of sodium nitrite $(12 \mathrm{mmol})$ in water $(5 \mathrm{~mL})$. The resulting solution of benzene diazonium chloride was added with stirring to a solution of $\mathbf{9 - 1 3}(8.0 \mathrm{mmol})$ and sodium acetate $(9.5 \mathrm{mmol})$ in methanol $(30 \mathrm{~mL})$. The reaction mixture was maintained at $0{ }^{\circ} \mathrm{C}$ for 4 hours. The product was filtered off, washed with methanol and then re-crystallized from ethanol.

\section{5,5-Dimethyl-3- $N$-(4-methylphenyl)imino-2,4-bis- (phenylhydrazone)cyclohexanone (29).}

Red plates (29\% yield); m.p 194-196 ${ }^{\circ} \mathrm{C}$;

IR (solid, KBr, vmax, $\mathrm{cm}^{-1}$ ): $3441(\mathrm{NH}), 1642$ (CO); ${ }^{1} \mathrm{H}-\mathrm{NMR}\left(\mathrm{CDCl}_{3}, 500 \mathrm{MHz}\right) \delta_{\mathrm{H}} \mathrm{ppm}: 1.39(\mathrm{~s}, 6 \mathrm{H}, 2$ $\mathrm{Me}), 2.32$ (s, 3H, Me), $2.71\left(\mathrm{~s}, 2 \mathrm{H}, \mathrm{CH}_{2}\right), 6.51(\mathrm{~d}, 2 \mathrm{H}$, J $8.4 \mathrm{~Hz}$, Ar-H), 6.78 (d, 2H, J $7 \mathrm{~Hz}$, Ar-H), 6.93 (t, $1 \mathrm{H}, J 7.6 \mathrm{~Hz}, \mathrm{Ar}-\mathrm{H}), 7.06$ (t, $1 \mathrm{H}, J 6.9 \mathrm{~Hz}, \mathrm{Ar}-\mathrm{H})$, 7.15 (d, 4H, J 7.7 Hz, Ar-H), 7.22-7.29 (m, $5 \mathrm{H}$, Ar-H+NH), 14.5 (s, 1H, $\mathrm{D}_{2} \mathrm{O}$ exchangeable $\left.\mathrm{NH}\right)$.

Anal. Calc for $\mathrm{C}_{27} \mathrm{H}_{27} \mathrm{~N}_{5} \mathrm{O}$ (437.53): C, 74.11; H 6.22; N, 16.00.Found:C, 74.20; H 6.39; N, 16.19.

5,5-Dimethyl-3- $N$-(2-methylphenyl)imino-2,4-bis(phenylhydrazone)cyclohexanone (30).

It was obtained as brown plates (35\% yield);m.p. $150-152^{\circ} \mathrm{C}$.

IR (solid, KBr, vmax, $\mathrm{cm}^{-1}$ ): $3730(\mathrm{NH}), 1646(\mathrm{CO})$; ${ }^{1} \mathrm{H}-\mathrm{NMR}\left(\mathrm{CDCl}_{3}, 500 \mathrm{MHz}\right) \delta_{\mathrm{H}} \mathrm{ppm}: 1.40$ (s, 6H, 2Me), 2.22 (s, 3H, Me), 2.75 (s, 2H, $\mathrm{CH}_{2}, 6.56$ (dd, $2 \mathrm{H}, J 5 \mathrm{~Hz}, \mathrm{Ar}-\mathrm{H}), 6.70$ (dd, $1 \mathrm{H}, J 10 \mathrm{~Hz}, \mathrm{Ar}-\mathrm{H}), 6.94-$ $7.02(\mathrm{~m}, 2 \mathrm{H}, \mathrm{Ar}-\mathrm{H}), 7.06-7.09(\mathrm{~m}, 1 \mathrm{H}, \mathrm{Ar}-\mathrm{H}), 7.14-$ 7.21 (m, 3H, Ar-H), 7.26-7.27 (m, 2H, Ar-H), 7.29$7.32\left(\mathrm{~m}, 3 \mathrm{H}\right.$, Ar-H), 14.60, $14.88\left(2 \mathrm{~s}, 2 \mathrm{H}, \mathrm{D}_{2} \mathrm{O}\right.$ exchangeable, $2 \mathrm{NH}$ ),

${ }^{13} \mathrm{C}-\mathrm{NMR}\left(\mathrm{CDCl}_{3}\right) \delta_{\mathrm{c}} \mathrm{ppm}: 19.9$ (O-Me), $28.4(2 \mathrm{Me})$, 37.8 (C-5), 52.6 (C-6), 113.9, 116.1, 117.7, 121.4, 122.7, 125.5, 126.4, 126.5, 126.7,129.1, 129.2, 130.4, 136.9, 141.3 (Ar-C), 144.5 (C-4), 150.3 (C-2), 154.4 (C-3), 196.5 (C-1).

Anal. Calc for $\mathrm{C}_{27} \mathrm{H}_{27} \mathrm{~N}_{5} \mathrm{O}$ (437.53): C, 75.65; H, 6.95; N, 12.60. Found: C, 75.29; H, 6.93; N, 12.97. 
3- $N$-(4-Chlorophenyl)imino-5,5-dimethyl-2,4-bis(phenylhydrazon)cyclohexanone(31).

Red plates (52 \%yield); m.p. $198-200^{\circ} \mathrm{C}$;

IR (solid, KBr, vmax, $\mathrm{cm}^{-1}$ ): $1638 \mathrm{~cm}^{-1}$ (CO);

${ }^{1} \mathrm{H}-\mathrm{NMR}$ (DMSO-d $\left.6,500 \mathrm{MHz}\right) \delta_{\mathrm{H}} \mathrm{ppm}: 1.31$ (s, 6H, 2Me), 2.82 (s, 2H, $\left.\mathrm{CH}_{2}\right), 6.70$ (d, $\left.2 \mathrm{H}, J 8.6 \mathrm{~Hz}, \mathrm{Ar}-\mathrm{H}\right)$, 6.96 (t, 2H, J 7.4 Hz, Ar-H), 7.07,7.10 (2d, 2H, J 8.6 $\mathrm{Hz}, J 7.5 \mathrm{~Hz}, \mathrm{Ar}-\mathrm{H}), 7.19$ (t, 1H, J 8.0 Hz, Ar-H), 7.24 (d, 4H, J 8.6 Hz, Ar-H), 7.38 (t, 4H, J 8.0 Hz, J 8.6Hz, Ar-H+NH) 14.00 (s, 1H, $\mathrm{D}_{2} \mathrm{O}$ exchangeable, $\left.\mathrm{NH}\right)$. Anal. Calc for $\mathrm{C}_{26} \mathrm{H}_{24} \mathrm{~N}_{5} \mathrm{OCl}$ (457.947): C, 68.18; $\mathrm{H}$, 5.28; N,15.29. Found: C, 68.39; H, 5.43; N, 15.46 .

\section{3-N-(2-Chlorophenyl)imino-5,5-dimethyl-2,4-bis-} (phenylhydrazone) cyclohexanon(32).

By fractional crystallization compound $\mathbf{3 2}$ was obtained as browen plates (75\%yield); m.p. $164-166^{\circ} \mathrm{C}$;

IR (solid, $\mathrm{KBr}$, vmax, $\mathrm{cm}^{-1}$ ): $3730(\mathrm{NH}), 1646(\mathrm{CO})$; ${ }^{1} \mathrm{H}-\mathrm{NMR}(500 \mathrm{MHz}, \mathrm{CDCl} 3) \delta_{\mathrm{H}} \mathrm{ppm}: 1.44$ (s, 6H, 2Me), 2.75 (s, 2H, $\mathrm{CH}_{2}$ ); 6.62 (d, 2H, J10 Hz Ar-H), 6.93-7.01 (m, 3H, Ar-H), 7.10(t,1H, J10 Hz, Ar-H), 7.18-7.26 (m, 4H, Ar-H), 7.28-7.33 (m, 3H, Ar-H), 7.45 (dd, 1H, J10 Hz Ar-H), 14.59, 14,64 (2s, 2H, $\mathrm{D}_{2} \mathrm{O}$ exchangeable, $2 \mathrm{NH}$ ).

${ }^{13} \mathrm{C}-\mathrm{NMR}\left(\mathrm{CDCl}_{3}\right) \delta_{\mathrm{c}} \mathrm{ppm}: 28.5(2 \mathrm{Me}), 37.7$ (C-5), 52.6 (C-6), 114.1, 115.9, 120.7, 121.7, 123.51, 125.6, 127.4, 129.1, 129.2, 129.9, 136.7, 141.2 (Ar-C), 141.4(C-4), 148.4 (C-2), 155.5 (C-3), 196.7 (C-1) Anal. Calc for $\mathrm{C}_{26} \mathrm{H}_{24} \mathrm{~N}_{5} \mathrm{OCl}$ (457.947): C, 68.18; $\mathrm{H}$, 5.28; N, 15.28. Found: C, 68.27; H, 5.03; N, 15.00. Compound 26a was separated from mother liquor in (40\% yield) and was idental to that obtained from method a.

\section{5,5-Dimethyl-3- $N$-(3-nitrophenyl)imino-2,4-bis- (phenylhydrazono)cyclohexanone (33).}

By fractional crystallization $\mathbf{3 3}$ was obtained as red plates (30\% yield); m.p. $163-165^{\circ} \mathrm{C}$;

${ }^{1} \mathrm{H}-\mathrm{NMR}(500 \mathrm{MHz}, \mathrm{CDCl} 3) \delta_{\mathrm{H}} \mathrm{ppm}: 1.45$ (s, 6H, 2Me), 2.73 (s, 2H, $\mathrm{CH}_{2}$ ), 6.59 (d, 2H, J5 Hz Ar-H), $7.00(\mathrm{t}, 1 \mathrm{H}, J 10 \mathrm{~Hz}, \mathrm{Ar}-\mathrm{H}), 7.09$ ( t, 2H, J $10 \mathrm{~Hz}$, Ar-H) 7.17-7.20 (m, 2H, Ar-H), 7.28-7.35 (m, 4H, Ar$\mathrm{H}), 7.47(\mathrm{t}, 1 \mathrm{H}, \mathrm{Ar}-\mathrm{H}), 7.82(\mathrm{~d}, 1 \mathrm{H}, J 5 \mathrm{~Hz}, \mathrm{Ar}-\mathrm{H})$, 7.89(dd, 1H, J10 Hz, $5 \mathrm{~Hz}, \mathrm{Ar}-\mathrm{H}), 14.55,14.65$ (2s, $2 \mathrm{H}, \mathrm{D}_{2} \mathrm{O}$ exchangeable, $\left.2 \mathrm{NH}\right)$,

${ }^{13} \mathrm{C}-\mathrm{NMR}\left(\mathrm{CDCl}_{3}\right) \delta_{\mathrm{c}} \mathrm{ppm}: 28.4(2 \mathrm{Me}), 37.9(\mathrm{C}-5)$, 52.5 (C-6), 114.3, 114.5, 115.7, 117.1. 122.2, 125.3, 125.7, 126.1, 129.3, 129.3, 129.8, 136.5, 140.9, 144.0 (Ar-C), 149.1 (C-4), 152.5 (C-2), 155.4 (C-3), 196.7 (C-1).

Anal. Calc for $\mathrm{C}_{26} \mathrm{H}_{24} \mathrm{~N}_{6} \mathrm{O}_{3}(468.5)$ : C, 66.65; H, 5.16; N, 17.94. Found: C, 66.40; H, 5.0; N, 17.80.

Compound 26b was separated from mother liquor in $15 \%$ yield, and it was identical to that obtained from method a.

5,5-Dimethyl-2,4-bis-(phenylhydrazone)cyclohexan-1,3-dioxime(35).

General method. A solution of compounds 29-33 $(0.3 \mathrm{mmol})$ in ethanol $(15 \mathrm{~mL})$ was treated with hydroxylamine hydrochloride $(0.7 \mathrm{mmol})$ and sodium acetate $(0.7 \mathrm{mmol})$. The reaction mixture was boiled under reflux for 4-5 hours. It was left to cool, and the product was filtered off, repeatedly washed with water and dried. It was re-crystallized from ethanol to give 35 as yellow crystals in $86,85,56$, and $58 \%$ yield from 29-33, respectively, m.p. $179-181^{\circ} \mathrm{C}$;

IR (solid, $\mathrm{KBr}$, vmax, $\mathrm{cm}^{-1}$ ): $3217 \mathrm{~cm}^{-1}(\mathrm{NH})$,

${ }^{1} \mathrm{H}-\mathrm{NMR}\left(\mathrm{CDCl}_{3}, 300 \mathrm{MHz}\right) \delta_{\mathrm{H}} \mathrm{ppm}: 1.31(\mathrm{~s}, 6 \mathrm{H}$, $2 \mathrm{Me}), 2.81\left(\mathrm{~s}, 2 \mathrm{H}, \mathrm{CH}_{2}\right), 6.86-7.40(\mathrm{~m}, 10 \mathrm{H}, \mathrm{Ar}-\mathrm{H})$, $8.22,12.35,12.93,15.06\left(4 \mathrm{~s}, 4 \mathrm{H}, \mathrm{D}_{2} \mathrm{O}\right.$ exchangeable, $2 \mathrm{OH}, 2 \mathrm{NH})$;

MS (m/z \%): $378\left(8, \mathrm{M}^{+\cdot}\right), 360\left(18, \mathrm{M}^{+\cdot}-\mathrm{H}_{2} \mathrm{O}\right), 342$ $\left(17 \mathrm{M}^{+\cdot}-2 \mathrm{H}_{2} \mathrm{O}\right)$.

Anal. Calc for $\mathrm{C}_{20} \mathrm{H}_{22} \mathrm{~N}_{6} \mathrm{O}_{2}$ (378.43): C 63.47; H 5.86; N 22.21. Found: C 63.58; H, 5.82; N, 22.37.

\section{References}

1- L. Yang, Y. Wu, Y. Yang, C. Wen, J-P. Wan, Catalyst-free synthesis of 4-acyl-NH-1,2,3triazoles by water-mediated cycloaddition reactions of enaminones and tosyl azide, Beilstein J. Org. Chem., 2018, 14, 2348-2353. J.V. Greenhill, I. Chaaban, P. J. Steel, Functionalized Enaminones and their use in Heterocyclic Synthesis, J. Heterocycl. Chem., 1992, 29, 1375-1383.

2- Y. Guo, Y. Xiang, J-P. Wang, Thermoinduced free-radical C-H acyloxylation of tertiary enaminones: catalyst-free synthesis of acyloxyl chromones and enaminones, Org. Lett., 2018, 20, 3971-3974. D.V. Tinh, M. Fischer, W. Stadlbauer, Ring Closure Reactions of Cyclic 2-Arylaminomethylene-1,3-diones, J. Heterocycl. Chem.1996, 33, 905-910.

3- A-Z.A. Elassar, A.A. El-Khair, Recent Developments in the Chemistry of Enaminones, Tetrahedron 2003, 59, 8463-8480.

4- S.A. Shawali, T.A. Farghaly, A.R. Al dahshoury, Synthesis, Reactions and Antitumor Activity of New $\beta$-Aminovinyl-3-Pyrazolyl Ketones, Arkivoc, 2009, (xiv), 88-99.

5- S.M. Al-Mousawi, M.A. El-Apasery, M.H. Elnagdi, Enaminones in Heterocyclic Synthesis: A Novel Route to Tetrahydropyrimidines, Dihydropyridines,

Triacylbenzenes and NaphthofuransUnder Microwave Irradiation, Molecules, 2010, 15, 58-67.

6- B. Govindh, B.S. Diwakar, Y.L.N. Murthy, A Brief Review on Synthesis \&Applications of $\beta$-Enamino Carbonyl Compounds, Org. Commun., 2012, 105-119.

7- A.A. E-H. Hassan, Heterocyclic Synthesis via Enaminones: Synthesis and Molecular Docking Studies of Some Novel Heterocyclic Compounds Containing Sulfonamide Moiety, Inter. J. Org. Chem., 2014, 4, 68-81. 
8- F. Al-Omran, A. El-Khair, The Behavior of 3-Anilinoenone and N-Phenyl Cinnamamide towards Carbon Nucleophiles: Spectroscopy and X-Ray Studies Reveal Interesting New Synthesis Routes to Nicotinonitriles and Tetrahydropyridine-3- Carbonitrile, Org. Chem. Curr. Res., 2014, 3, 123.

9- Y.N. Mabkhot, F.D. Aldawsri, S.S. AlShowman, A. Barakat, S.M. Soliman, M. I. Choudhary, S. Yousuf, M.S. Mubarak, T.B. Hadda, Novel Enaminone Derived from Thieno[2,3-b]Thiene: Synthesis, X-Ray Crystal Structure, HOMO, LUMO, NBO Analyses and Biological Activity, Chem. Central J. 2015, 9.

10- I.H. El-Azab, L.M.Break, Z.A.A.El-Zahrani, Syntheses of Enaminone-Based Heterocyclic Compounds and Study their Biological Activity, Orien. J. Chem., 2016, 32, 2435-2449.

11- N.D. Eddington, D.S. Cox, R.R. Robert, J.P. Stables, C.B. Powell, K.R. Scott, EnaminonesVersatile Therapeutic Pharmacophores. Further Advances, Curr. Med. Chem., 2000, 7, 417436.

12- I.O. Edafiogho, O.A. Phillips, E.E. Udo, S. Santosh, B. Rethish, Synthesis, Antibacterial and Anticonvulsant Evaluations of Some Cyclic Enaminones, Eur. J. Med. Chem. 2009, 44, 967-975.

13- E.S.H. El Ashry, L.F. Awad, E.I. Ibrahim, O. Kh. Bdeewy, Synthesis of Antipyrine Derivatives Derived from Dimedone, Chinese J. Chem., 2007, 25, 570-573.

14- E.S.H. El Ashry, L.F. Awad, E.I. Ibrahim, O. Kh. Bdeewy, Microwave Irradiation for Accelerating the Synthesis of Acridine and Xanthene Derivatives from Dimedone, Arkivoc, 2006, (ii), 178-186.

15- N. Rashed, M. Sayed, E.S.H. El Ashry, Dibenzo[b,e][1,4]diazepin-1-one, Synthesis and Derivatization, J. Chinese Chem. Soc., 1993, 40, 189-194.

16- H. Abdel Hamid, A. Moussad, M. Sayed, E.S.H. El Ashry, Synthesis of 2-Aryl-4,5,6,7Tetrahydro-6,6-Dimethyl-2H-

Benzo[d][1,2,3]Triazol-4-ones, Org. Prep. Proceed. Int. 1993, 25, 569-575.

17- E.S.H. El Ashry, G.H. Labib, M. Shaban, F. El Sayed. Reactions of Hydrazines with Dimedones, Indian J. Chem. 1978, 16, 871-875.

18- E.S.H. El Ashry, L.F. Awad, Y. El Kilany, E.I. Ibrahim, Chapter 1 Dimedone: A Versatile Precursor for Annulated Heterocycles, Adv. Heterocycl. Chem., 2009, 98, 1-141.

19- J.V. Greenhill, Aromatic Enaminones. Part 1. Ultraviolet Absorption of N-Aryl Enaminones Derived from Dimedone, J. Chem. Soc. Perkin Trans 1, 1976, 2207-2210.

20- M. P. Sushmita, A. K. Verma, Coppercatalyzed stereo- and chemoselective synthesis of enaminones via Michael type addition, J.
Chem. Sci., 2018, 130:70 R. Dalpozzo, A. De Nino, M. Nardi, B. Russo, A. Procopio, Erbium(III) Triflate: A Valuable Catalyst for the Synthesis of Aldimines, Ketimines, and Enaminones, Synthesis, 2006, 1127-1132.

21- R.S. Bhosale, P.A. Suryawanshi, S.A. Ingle, M. N. Lokhande, S.P. More S.B. Man, S.V. Bhosale, Ionic Liquid Promoted Synthesis of $\beta$-Enamino Ketones at Room Temperature, Synlett, 2006, 6, 933-935.

22- B. Datta, M.B.M. Reddy, M.A. Pasha, Molecular Iodide- Catalyzed Mild and Effective Synthesis of $\beta$-Enaminones at Room Temperature, Synth. Commun., 2011, 41, 2331-2336.

23- M.A. Harrad, B. Boualy, L. El Rirdoussi, M.A.Ali, Aluminum Phosphate Catalyzed Free Solvent Preparation of $\beta$ - Enamino Esters, Am. J. Chem., 2012, 2, 271-276.

24- N.D. Koduri, H. Scoot, B. Hileman, J.D. Cox, M. Coffin, L. Glicksberg, S.R. Hussaini, Ruthenium Catalyzed Synthesis of Enaminons, Org. Lett., 2012, 14, 440-443.

25- M. Zhang, A. Abdukader, Y. Fu, C. Zhu, Efficient Synthesis of $\beta$-Enaminones and $\beta$ Enaminoesters Catalyzed by Gold(I)/ Silver (I) under Solvent-Free Conditions, Molecules, 2012, 17, 2812-2822.

26- M. Nisar, I. Ali, M.R. Shah, M. Qayum, M. UiHaq, U. Rashid, M. Islam, Efficient PPA-SiO Catalyzed Synthesis of $\beta$-Enaminones under Solvent-Free Conditions, Molecules, 2013, 18, 15182-15192.

27- R. Khajuria, Y. Saini, K.K. Kapoor, Ferric Nitrate Nonahydrate as a Mild and Efficient Catalyst for the synthesis of $\beta$-Enaminones, Indian J. Chem. 2014, 53B, 1122-1127.

28- C-L. Feng, N.N. Chu, S.G. Zhang, J. Cai, J.Q. Chen, H.Y. Hu, M. Ji, Solvent-Free Synthesis of $\beta$-Enamino Ketones and Esters Catalyzed by Recyclable Iron (III) Triflate, Chem. Papers, 2014, 68, 1097-1103.

29- B. Cui, R.U Wang, L.Z. Chen, Y Jin, G.F. Han, Synthesis of Enaminones in Aqueous Media Using Catalytic Dilute HCl, Synth. Commun., 2011, 41, 1064-1070.

30- S.U. Tekale, V.B. Jadhav, S.B. Munde, R.P. Pawar, Grinding Induced Solvent Free, Catalyst-Free Synthesis of $\beta$-Enaminones and $\beta$ - Enamino Esters der Chem. Sinica, 2015, 6, 38-41.

31- A. Kotali, V.P. Papageorgiou, Oxidation of the Dioximes of 1,3-Diketones with Lead TetraAcetate, J. Chem. Soc. Perk. Trans, 1, 1985, 2083-2086.

32- S.I. Zav'yalov, V.M. Medvedeva, Chemistry of 1,3-Cyclohexanedione, Russ. Chem. Bull., 1959, 8, 2062-2066.

33- N.N. Makhova, L. L. Fershtat, Recent advances in the synthesis and functionalization of 1,2,5- 
oxadiazole 2-oxides, Tetrahedron Lett., 2018, 59, 2317-2326. M. Boiani, H. Cerecetto, M. Gonzalez, M. Risso, C. Olea-Azae, O.H. Piro, E.E. Castellano, A.L. de Cerain, O. Ezpeleta, A. Monge-Vega, A. 1,2,5Oxadiazole N-Oxide Derivatives as Potential Anti-Cancer Agents: Synthesis and Biological Evaluation. Part IV, Eur. J. Med. Chem., 2001, 36, 771-782.

34- A. Vaidya, S. Jain, P. Jain, P. Jain, N. Tiwari, R. Jain, R. Jain, A. K. Jain, R. K. Agrawal, Synthesis and biological activities of oxadiazole derivatives: a review, Mini. Rev. Med. Chem., 2016, 16, 835-845. G. Aguirre, L. Boiani, H. Cerecetto, R. Di Maio, M. Gonzalez, W. Porcal, A. Denicola, M. Moller, L. Thomson, V. Tortora, Benzo [1,2-c]1,2,5-Oxadiazole N-Oxide Derivatives as Potential Antitrypanosomal Drugs. Part 3: Substituents- Clustering Methodology in the Search for New Active Compounds, Bioorg. Med. Chem., 2005, 13, 6324-6335.

35- L. Keurulainen, M. Heiskari, S.Nenonen, A. Nasereddin, D. Kopelyanskiy, T. O. Leino, J. Y-Kauhaluoma, C. L. Jaffe, P. Kiuru, Synthesis of carboxyimidamide- substituted benzo[c][1,2,5]oxadiazoles and their analogs and evaluation of biological activity against Leishmania donovani, Med. Chem. Comm., 2015, 6, 1673-1678.G.C. Tron, F. Pagliai, E. Del Grosso, A.A. Genazzani, G. Sorba, Synthesis and Cytotoxic Evaluation of Combrefurazans, J. Med. Chem., 2005, 48, 3260-3268.

36- K. Gajula, T. Maringanti, D. Biradar, V. Chamle, R. Alvala, R. Manchal, Synthesis and antibacterial activity of novel 4-phenyl-3-( (quinoxalin-2-yloxy)methyl)-1,2,5-oxadiazole 2-oxide derivatives, J. Chem. Pharm. Res., 2018, 10, 9-14 C. Velazquez, P.N.P. Rao, R. McDonald, E.E. Knaus, Synthesis and Biological Evaluation of 3,4-Diphenyl-1,2,5Oxadiazole-2-Oxides and 3,4-Diphenyl-1,2,5Oxadiazoles as Potential Hybrid COX-2
Inhibitor/Nitric Oxide Donor Agents, Bioorg. Med. Chem., 2005, 13, 2749-2757.

37- R.A. Olofson, J.S. Michelman, Furazan, J. Org. Chem., 1965, 30, 1854-1859.

38- Y. Kamitori, A Convenient and Facile Synthesis of 3-Trifluoromethyl-1,2,5Oxadiazoles with the Use of Silica Gel as an Effective Catalyst, Heterocycles, 1999, 51, 627-630.

39- K.W.J. Baker, A.R. March, S. Parsons, R.M. Paton, 3,5-Dipyranosyl-1,2,5-Oxadiazole-2Oxides: Synthesis and X-Ray Structure, Tetrahedron, 2002, 58, 8505-8513.

40- L.S. Constantinova, S.A. Amelichev, S.G. Zlotin, M.I. Struchkova, T.I. Godovikova, O.A. Rakitin, [1,4]Dithiino[2,3-c:5,6c']Bis[1,2,5]Oxadiazole Di-N-Oxide: Synthesis and Oxidation to Mono- and Bis-S- Oxides, Mendeleev Commun., 2015, 25, 339-340.

41- M.G.B. Drew, B. Vickery, G.R. Willy, Phenylhydrazone Derivatives of Dimedone: Hydrogen Bonding, Spectral $\left({ }^{13} \mathrm{C}\right.$ and ${ }^{1} \mathrm{H}$ Nuclear Magnetic Resonance) and Conformational Consideration. Crystal and Molecular Structures of 5,5-

Dimethylcyclohexane-1,2,3-Trione 2-(4methylphenylhydrazone) (1) and 5,5Dimethylcyclohexane-1,2,3-Trione 2-(4-Nitrophenylhydrazone) (2), J. Chem. Soc. Perkin Trans., 1982, 2, 1297-1303

42- P. Simunek, A. Lycka, V. Machacek, Synthesis, ${ }^{1} \mathrm{H},{ }^{13} \mathrm{C}$, and ${ }^{15} \mathrm{~N}$ NMR Study of Azo Coupling from Enaminones, Eur. J. Org. Chem., 2002, 2764-2769

43- P. Simunek, L. Luskova, M. Svboodova, V. Bertolasi, A. Lycka, V. Machacek, Synthesis and Structure of Some Azo Coupled Cyclic $\beta$-Enaminones Magn. Reson. Chem., 2007, 45,330-339.

44- S.R. Jain, A. Kar, The Antibacterial Activity of Some Essential Oils and their Combinations, Planta Med., 1971, 20, 118-123.

45- I. Jirovsky, Studies on Enaminoketones, Can. J. Chem., 1974, 52, 55-65. 